\title{
SIGNIFYING HERITAGE IN AMAZON: A PUBLIC ARCHAEOLOGY PROJECT AT VILA DE JOANES, MARAJÓ ISLAND, BRAZIL*
}

\author{
LOS SENTIDOS DE PATRIMONIO EN LA AMAZONIA: UN PROYECTO DE \\ ARQUEOLOGÍA PÚBLICA EN VILA DE JOANES, ISLA DE MARAJÓ, BRASIL
}

\author{
Marcia Bezerra ${ }^{1,2}$
}

\begin{abstract}
The paper summarizes the initial results of a public archaeology project undertaken at Vila de Joanes, a fishing village in the Amazon, on Marajó Island, where I conducted research with a site that was a religious mission from the XVII century. By reflecting about the local communities' ideas about the site I explore the underlying logic of collecting artifacts -a local practice- and the subsequent organization of "small collections," arguing that collecting in this context should not be considered "destruction" but rather as a particular form of heritage appropriation. By exercising such reflections the study aims to better understand the relationship between small scale communities and archaeological patrimony in the Amazon as well as to aid in the development of distinct public policies which are appropriate for local preservation.
\end{abstract}

Key words: Public archaeology, patrimony, collections. Marajó Island, Amazon.

El propósito central de este artículo es exponer los resultados iniciales de un proyecto de arqueología pública realizado en Vila de Joanes, un pueblo pesquero en la Amazonia, en la isla de Marajó, donde hice la investigación arqueológica en el sitio asociado a una misión religiosa del siglo XVII. A partir de las ideas de la comunidad local acerca de este sitio se estudió la lógica que subyace a la colección de artefactos, una práctica local, y la subsecuente organización de "pequeñas colecciones". En este contexto se argumenta que este acto de coleccionar no debería ser considerado "destructivo" sino una forma particular de apropiación de su herencia cultural. A través de esta reflexión, el objetivo de este estudio es entender las relaciones entre pequeñas comunidades locales y el patrimonio arqueológico en la Amazonia, como así también aportar al desarrollo de políticas públicas distintivas, apropiadas para la preservación del patrimonio local.

Palabras claves: arqueología pública, patrimonio, colección, Marajó, Amazonia.

Over the last decades Amazonian archaeology has made great advances, especially concerning the comprehension of the complex relationships between past groups and the landscape. The idea of social complexity in pre-colonial Amazon embraces a set of aspects related to the "social experience of material world" (Miller 2005) in the past. The diversity of pre-colonial sites -with mounds (Brochado 1980; Meggers and Evans 1954; Roosevelt 1991; Schaan 2001), geoglyphs (Schaan et al. 2008), anthropic dark earths (Petersen et al. 2001), roads
(Heckenberger 2005), megaliths (Cabral and Saldanha 2008), shell mounds (Silveira and Schaan 2005), caves (Guapindaia 2008) and rock art sites (Pereira 2003)- and the increasing number of academic as well as contract archaeology projects have transformed ancient occupation of Amazonian into one of the most exciting forum for debating key issues in contemporary archaeology.

Alongside these refreshing debates regarding the archaeological record in Amazon, there has also been an emergence of a new perspective which

* Artículo seleccionado del conjunto de ponencias presentadas en el Simposio Shifting from Object-centered Research to People-focused Application: Current Approaches to Public Archaeology from Latin America and the Caribbean, realizado en el marco de la 75 reunión anual de la Sociedad de Arqueología Americana, Saint Louis, Missouri, EUA, abril 2010. Este manuscrito fue evaluado por investigadores externos y editado por Reiko Ishihara-Brito y Cameron Griffith, en su calidad de editores invitados de la Revista.

1 Programa de Pós-Graduação em Antropologia, Universidade Federal do Pará, Brasil. Conselho Nacional de Desenvolvimento Científico e Tecnológico, Brasil.

2 Adjunct Faculty Member, Department of Anthropology, Indiana University, USA. marciabezerrac14@ gmail.com 
aims to incorporate discussions on the complex relationships between contemporary communities, archaeologists and the material culture of the past (Colwell-Chanthaphonh and Ferguson 2008). What distinguishes previous discussions on these relationships from this new approach is the perception of the other (the local communities) as a collaborator of the archaeological research (Gnecco and Ayala 2011; Gnecco and Hernandez 2008; Green et al. 2003; Londoño 2003). Emic perspectives concerning material culture have been considered relevant in understanding and preserving the past and in learning about the diversity of representations and attitudes towards archaeological objects in the present. In this sense, it is pertinent to reflect critically about the "material experience" (Miller 2005) of local communities with the things of the past in the Amazon.

For decades, researchers and cultural managers have tried to protect archaeological heritage from destruction. Law enforcement by federal management agencies as well as educational heritage projects -required by contract archaeology practices in Brazil- is considered crucial in the struggle for preservation (Bezerra 2010). Brazilian legislation protects archaeological resources, whether on public or private lands, and the punishment for destruction includes fines and prison sentences (IPHAN 2006). But these efforts have proven insufficient in slowing the growth of site destruction. The primary contributing factors are: (1) trade of archaeological objects; (2) removal of dark earth, known as terra preta, for sale; (3) development projects; and (4) disordered tourism (Lima 2007; Schaan 2007). However, as Londoño discusses:

Here appears a first great tension, as the practice of scientific archaeology is proposed from the legal perspective of the state... as the only way to manipulate this category of material culture (Londoño 2003:6, translation by author).

The core of the problem lies in the asymmetrical relationships between the state and local communities, as well as between archaeologists and native communities.

\section{The "Endangered" Past in Amazon}

In small villages in the Amazon, houses are built over archaeological sites, and local people make their farm plots in Amazonian dark earth (terra preta). They reuse ancient ceramic vessels to store water and manioc flour, and casually collect objects found alongside rivers, creeks and roads for personal collections. On Marajó Island local land owners have long been interested in the material culture of the Marajoara phase (AD 400-1,300). Their interest in archaeological objects implies the removal of hundreds of pieces from pre-colonial sites to form their own collections (Schaan 2009b). Brazilian and foreigner collectors encourage looting and contribute to the increase of practices by "subsistence diggers" (Brodie 2006:5). However, this paper is not concerned with "subsistence diggers" (Brodie 2006:5), or the category of looters known as huaqueros in Peru or tombarolli in Italy. The main concern here is with the socio-cultural practices of small-scale communities in the Amazon, which are not related to the illegal trafficking of antiquities (Lima 2007).

In this sense it is critical to consider: Do members of such communities belong in the same category as that of the large-scale collectors? Do they, in fact, represent a threat to archaeological heritage? How can archaeologists deal with these practices? In Brazil these practices are considered illegal by the state. Nevertheless, they could be approached as a local appropriation of the past, which implies a critical review of our ideas and attitudes towards local uses of heritage. This review does not imply that acts, which promote the destruction of patrimony, are being supported. There is, however, little research on the practice of collecting, which is itself of great relevance, for there "appears to be diverse types of collectors and diverse reasons to collect" (Belk 2008:539).

Reflecting on the Vila de Joanes case enables us to outline a new approach to understanding why people collect archaeological things, which is also a crucial step towards preventing site destruction. The main argument of this paper is that collecting, in this context, should not be considered "looting" or "destruction", but rather as a particular form of heritage perception and appropriation. We also should think critically about notions of "destruction" and "preservation".

\section{Vila de Joanes}

Vila de Joanes is a small fishing village that is popular among both Brazilian and foreign tourists. 
During the month of July, in the Amazonian summer, the population of Joanes may undergo a fourfold increase. The economy is based on agriculture, fishing and tourism. The village is located in the eastern portion of Marajó Island, which is itself situated in an archipelago of the same name, in the Amazon River Delta on the northern part of South America. The archipelago of Marajó covers an area of approximately $50,000 \mathrm{~km}^{2}$ and encompasses diverse landscapes of grasslands and forests dotted with archaeological sites that date from 5,000 BP to the arrival of Europeans in the sixteenth century.

Little is known about the shell middens ( $\mathrm{sam}$ baquis) that characterize the first occupations. Marajó pre-colonial history is known mainly through research carried out in the artificial mounds (tesos) associated with the Marajoara phase by researchers such as Meggers and Evans (1954) in the fifties, Brochado (1980) in the eighties, Roosevelt (1991) in the nineties and Schaan (2001) most recently. These scholars have contributed to the advancement of archaeological debates related to the emergence of complex societies in pre-colonial Amazon.

Part of the remnant populations from the Marajoara phase seems to have been incorporated into the religious missions that were implanted on the island in the seventeenth century (Marques and Bezerra 2008; Schaan 2009a, b). Due to the density of the indigenous population of northern Brazil, the area became attractive to missionaries during the colonial period (Fausto 2003:91). A major part of the history of Portuguese colonization in America took place far from the major administrative centers. Villages and settlements established in remote places came to resemble small islands, in which new modes of life merged resulting from circumscription, isolation and coexistence among individuals with distinct senses of belonging (Mello e Souza 1997).

It was in this context during the seventeenth century that a religious mission was established in what was then known as Vila de Monforte. Archaeological research (Marques and Bezerra 2008, 2009; Schaan and Marques 2006) has revealed evidence of daily life in this mission and the interaction between indigenous and European people, which makes the study and preservation of the Joanes site an important venue for understanding contact processes in colonial Amazon.

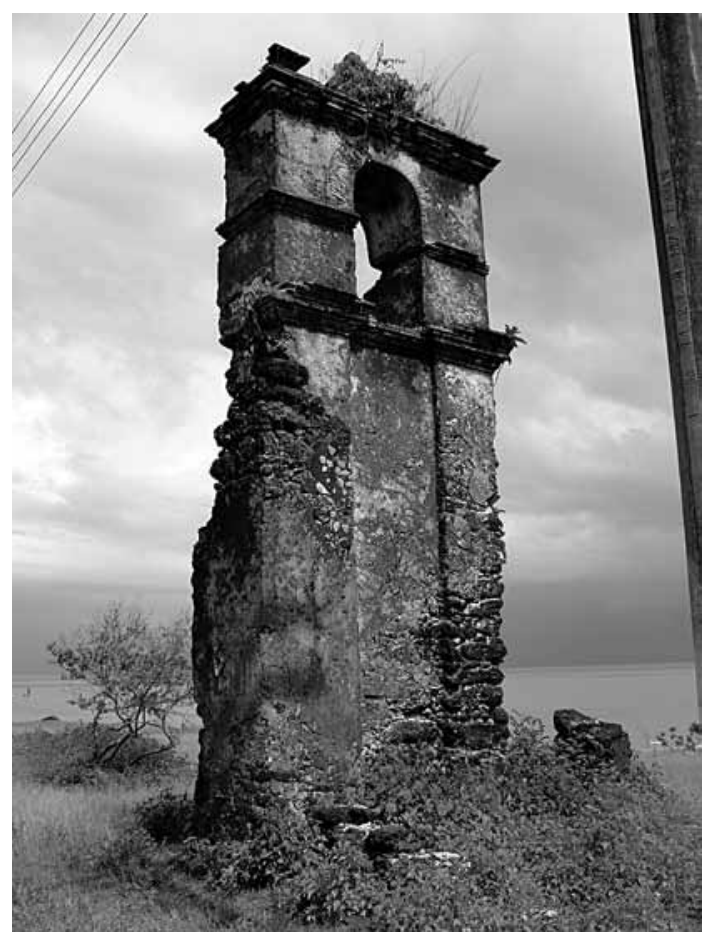

Figure 1. Archaeological site of Joanes (PA-JO-46). Photograph by Flávio Silveira.

Sitio Arqueológico de Joanes (PA-JO-46). Fotografía de Flávio Silveira.

\section{Studying the Historic Site of Joanes (PA-JO-46)}

The Joanes historical site is constituted by indigenous and colonial remains, particularly the ruins of the Church of Nossa Senhora do Rosário (Figure 1), part of a religious mission from the seventeenth century (Schaan and Marques 2006). Either Franciscans or Jesuits may have founded the church, which may represent the first religious mission to be established on Marajó Island (Lopes 1999).

The site's historical and archaeological significance motivated the Brazilian National Institute for Historic and Artistic Patrimony (Instituto do Patrimônio Histórico e Artístico Nacional, IPHAN) to develop projects aiming for its preservation. In 1986, during expansion of the local school building, vestiges of the old mission were found, which required further investigation. In 1999 Lopes opened small test pits, mapped surface material and surveyed historical sources. In 2006, IPHAN, concerned about the state of preservation of the site, funded a research and heritage education project, which was carried 
out in partnership with the community. However, the site became an issue of political dispute during municipal elections. The conflicts ended up provoking acts of vandalism, such as the destruction of the tourist information markers placed by researchers, and instigated a movement against archaeologists regarding the removal of archaeological material from the village, despite the absence of an appropriate place to store them in the area. The tension was somewhat controlled when researchers arranged to leave part of the archaeological material under the responsibility of the local school, where it remains until now (Schaan and Marques 2006).

In 2008 IPHAN supported a new archaeological and heritage education project in order to restore engagement with the local community and repair the damage done to the site markers. The project was coordinated by Marques and Bezerra (2008). Marques had taken part in all of the prior research on the site and had also co-directed the 2006 field season (Schaan and Marques 2006). Throughout the 2008 season the team aimed at engaging with the local community (including the residents) in field research, holding meetings with small groups, participating in festivals and acknowledging their attitudes towards archaeological heritage. The political conflict faced by the previous team had been diminished in some important ways, and residents gradually began seeking out the researchers, demonstrating curiosity about the excavations and discussing matters of local interest, such as building a museum to "tell the history of Joanes".

During the last field season, in 2009, a display table was set up under the excavation shelter, with objects recovered from the site. Another display was further organized at the local school (Marques and Bezerra 2009) (Figure 2). Both efforts revealed changes in the attitudes of residents towards local archaeological heritage, and highlight the need for understanding the logic underlying collecting practices and the relationships between local individuals and the ruins. Aiming at further developing these questions, a public archaeology project was designed and begun in the same year.

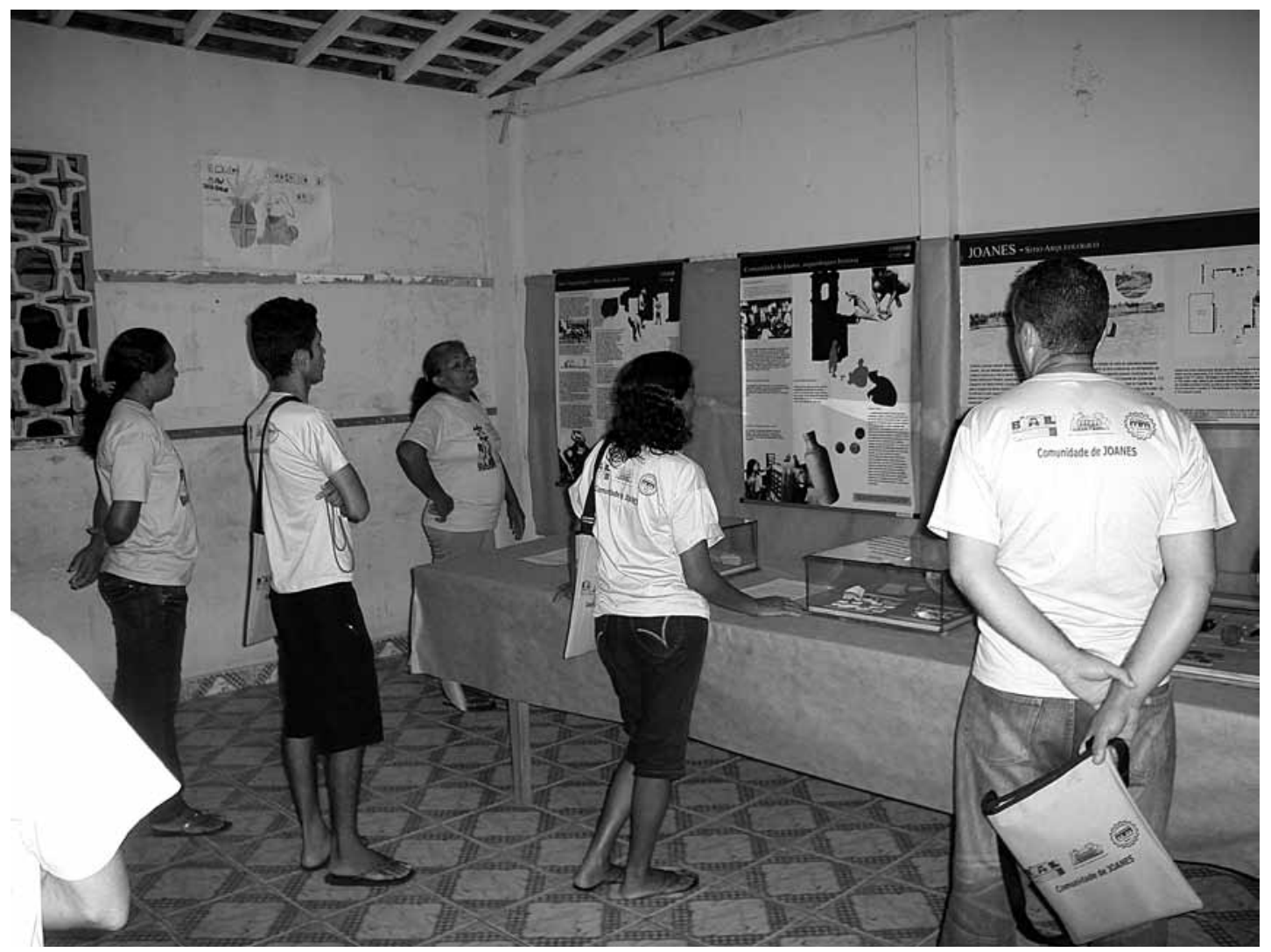

Figure 2. Schoolteachers at the archaeological display in the local school. Photograph by Marcia Bezerra.

Profesores de enseñanza básica en exposición arqueológica en la escuela local. Fotografía de Marcia Bezerra. 


\section{The Public Archaeology Project (2009-2013)}

The reflections presented here resulted from the initial phase of the research, which is funded by the $\mathrm{CNPq}$ (Conselho Nacional de Desenvolvimento Científico e Tecnológico, or the National Research Council in Brazil). The articulation between archaeology and ethnography is the focus of the project, where "Archaeology is a Subject of Ethnography" (Castañeda 2008:30-31). By means of interviews conducted with various groups in the village and participant observation of the daily lives of residents, the main research goals consist of examining: (1) the relation between social memory and archaeological heritage; (2) the denial of an indigenous past; (3) the role of the ruins in residents' daily lives; (4) the practice of collecting archaeological objects; and (5) the impact of the knowledge produced by archaeology projects, among other questions. The resulting analysis will provide a critical assessment of the ethos of archaeology in the Amazon and a stimulus for the development of public concern regarding archaeological heritage management based on emic perspectives (Bezerra 2010). The focus here is on the practice of collecting and the role of the ruins in the landscape perceived by the residents.

The study goes against a reductionist approach, which (1) considers the act of collecting artifacts a threat to preservation; (2) attributes looting to the ignorance of local populations; and (3) states that communities are responsible for its destruction. The central idea is that collecting in contexts such as Joanes cannot be seen as destruction or a threat to Amazonian archaeological heritage, but as a form of dealing with the past. The indigenous past is often denied by the local narratives. However, it seems to be appropriated through a reification process of material culture. Similarly, the ruins are turned into a vernacular landscape. There is no strangeness between them and the local communities. In this process, the ruins are not devalued, but re-defined by them (Bezerra 2009).

\section{In Small Things Collected ${ }^{1}$ : The Local Collectors of Joanes}

Joanes is a small-scale community. There are clearly demarcated boundaries and close kinship bonds among local residents. The village is composed of those born in Joanes, known as "Children of Joanes", and by the "outsiders", residents coming from other parts of the country and foreigners (see Elias and Scotson 2000).

The preservation of archaeological heritage in Joanes is not equally important to all these communities. For some, the ruins should be preserved and used for tourism in order to improve the economy; for others, it is necessary to build a local museum for education. There are also those who think that heritage preservation does not contribute to the development of the village. A significant share of local commerce (shops, inns, stores, and others) is owned by "outsiders". It has become evident in the discourses with residents that there exists a division in the perception of archaeological heritage. Most residents have an ambivalent relationship with the local heritage. The school has been built over part of the site. Some schoolteachers consider heritage as a key component to improve education and to build citizenship. Others view it as a barrier to expanding the school infrastructure, as they cannot construct rooms over the site area.

Groups of tourists, both Brazilian and foreigners, frequently climb the ruins, especially the church tower, in order to take pictures. They also park cars throughout the site area. The local tour guides provide decontextualized and groundless information, often leading to fantastic interpretations, such as the existence of a hidden volcano which supplied the rocks for building the church and a supposed ancient Maya occupation of the island.

The residents' image of the past is formed of narratives of ghost apparitions. As is common in the rest of the Amazon region, inhabitants recount tales of hauntings and speak of the existence of hidden treasures. They materialize these narratives by collecting dozens of archaeological objects. In the words of one of our students: "they build other archaeological sites at home" (A. Queiroz personal communication 2010). All over the Amazon, in villages near pre-colonial sites the axes and ceramic vessels draw the most attention. These are displayed in carefully organized boxes, but are also used as paper and door weights. Ancient ceramic vessels serve as recipients for water and manioc flour storage and their pottery sherds are used as plant supports in order to maintain humidity, or as playthings for children, who "prefer the cute ones", meaning the decorated pottery.

In Joanes, the material repertoire includes indigenous ceramics, glass, clay pipes, animal bones, and construction materials from the sixteenth to 


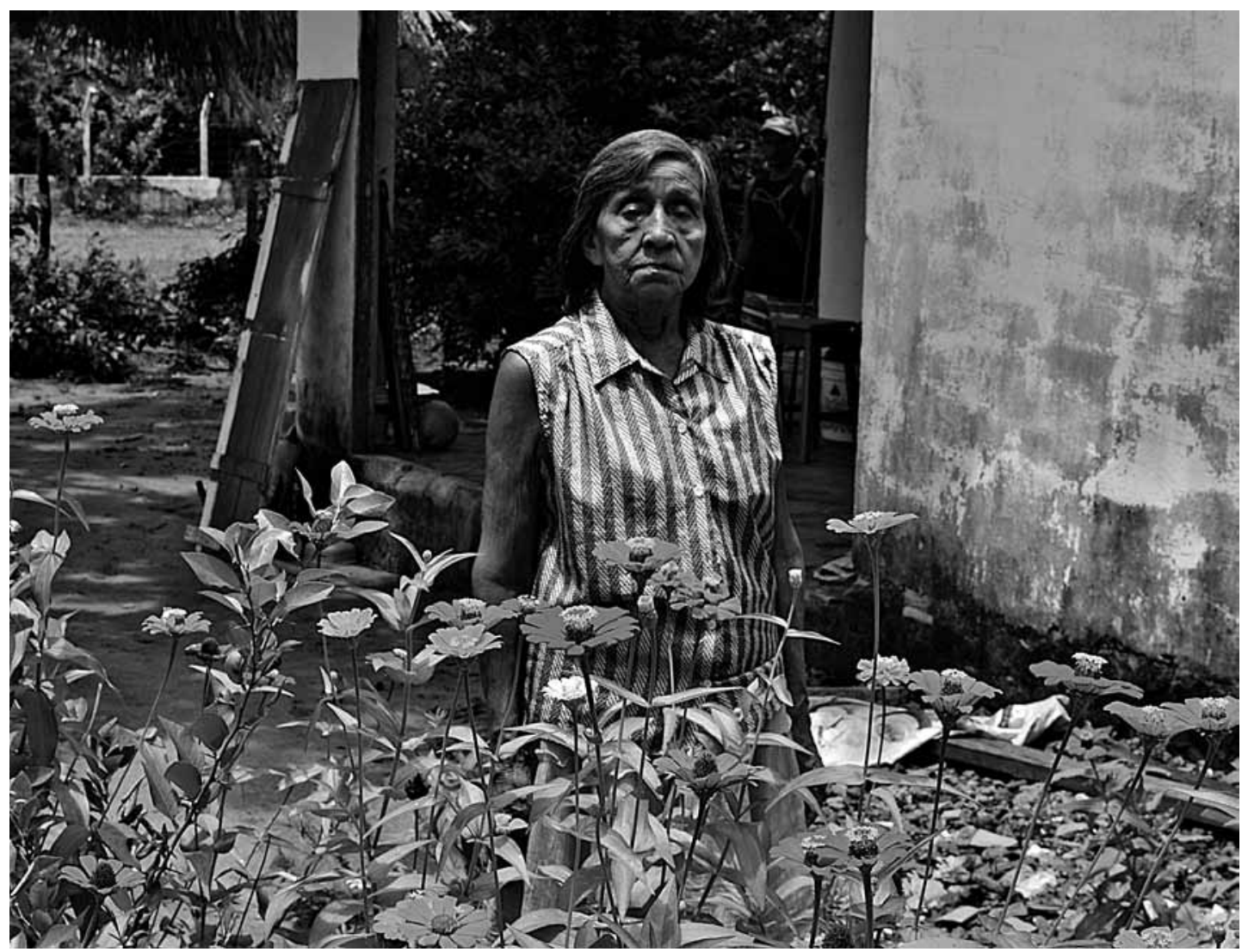

Figure 3. Dona Maria José, local resident. Photograph by Antonio Garcia.

Doña Maria José, residente local. Fotografía de Antonio Garcia.

the nineteenth centuries. The heavy rainfall in the Amazon leads to the appearance of pieces on the surface dispersed throughout the village. Residents collect surface artifacts while working on their yards or planting their crops. There is no record of illegal excavations.

During the interviews, older residents reported on finding coins and beads in the ruins ever since their childhood. According to Dona Maria José, a retired employee of the school and a ceramic maker (Figure 3), they did not keep the objects that they found. Her description, like those of other residents, indicates that there was such a significant volume of objects that they were abandoned in the area. To her, the amount of material indicates that "there must have been lots of Indians here because there are a lot of beads and they liked to adorn themselves". She regrets that "now it's all civilized" and "all that remains are memories of the stories". Dona Maria José says that she knows nothing about the Indians who lived there and adds that "there are people who think I look like an Indian; I don't know, but I believe I am". She is sorry that she did not keep any of the coins that she had found during her childhood.

Residents often maintain their small collections with care worthy of a museum curator. This is the case with the schoolteacher, Dona Vera, who has her young granddaughter clean the artifact fragments that she finds in the backyard (Figure 4). Besides the "restoration" of broken objects, Dona Vera also tells us where they were found and asks what can be done to preserve them. She wants to donate her collection to the "Joanes Museum," that does not exist yet (Figure 5). Dona Vera and other residents donated several pieces to the archaeological missions. During the 2008 mission, their names were recorded on cards and displayed alongside the donated objects. Having their names displayed on these labels became more important to them than the objects donated. The acknowledgment and prestige provided by the small card influenced the 


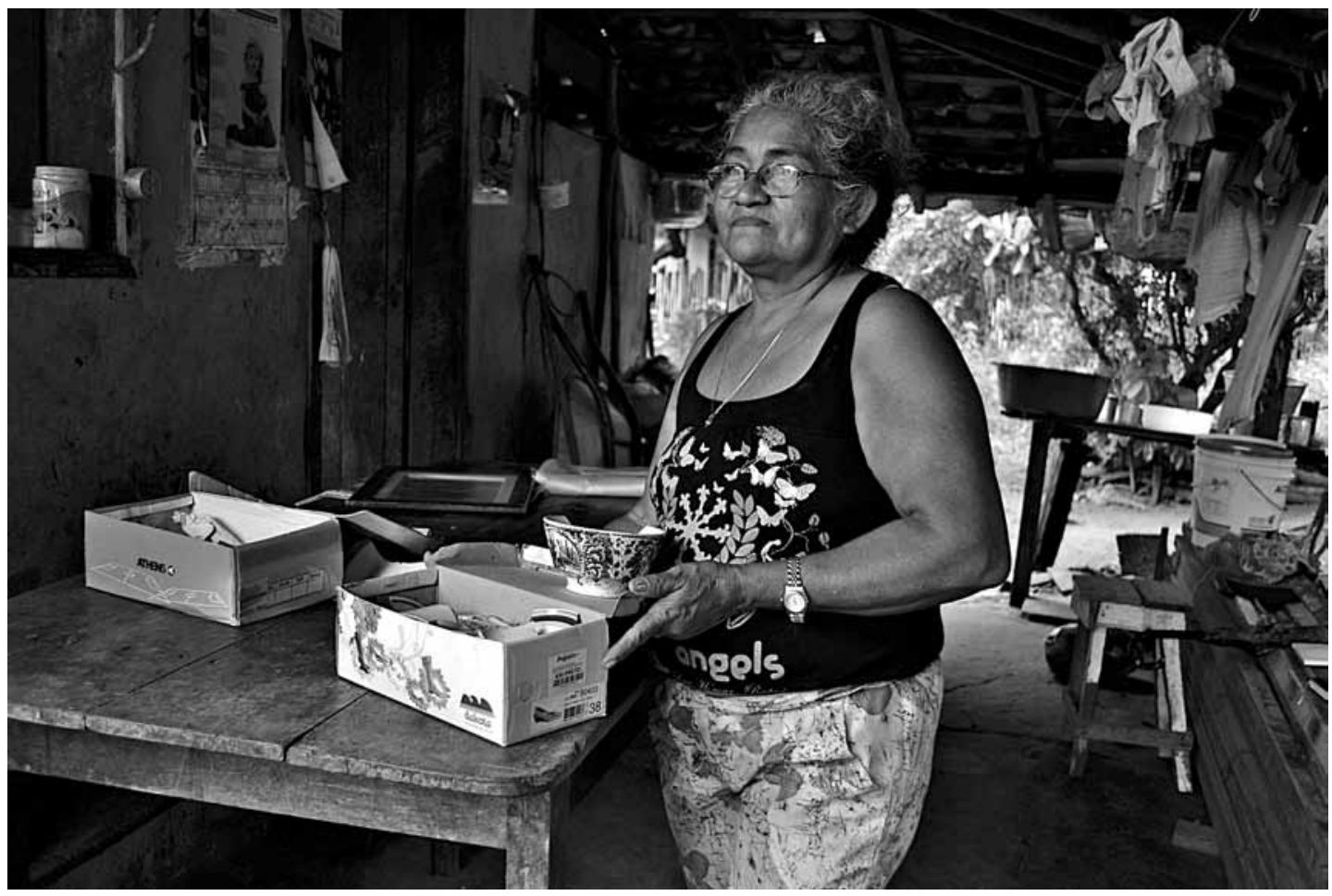

Figure 4. Dona Vera and her collection of artifacts. Photograph by Antonio Garcia.

Doña Vera y su colección de artefactos. Fotografía de Antonio Garcia.

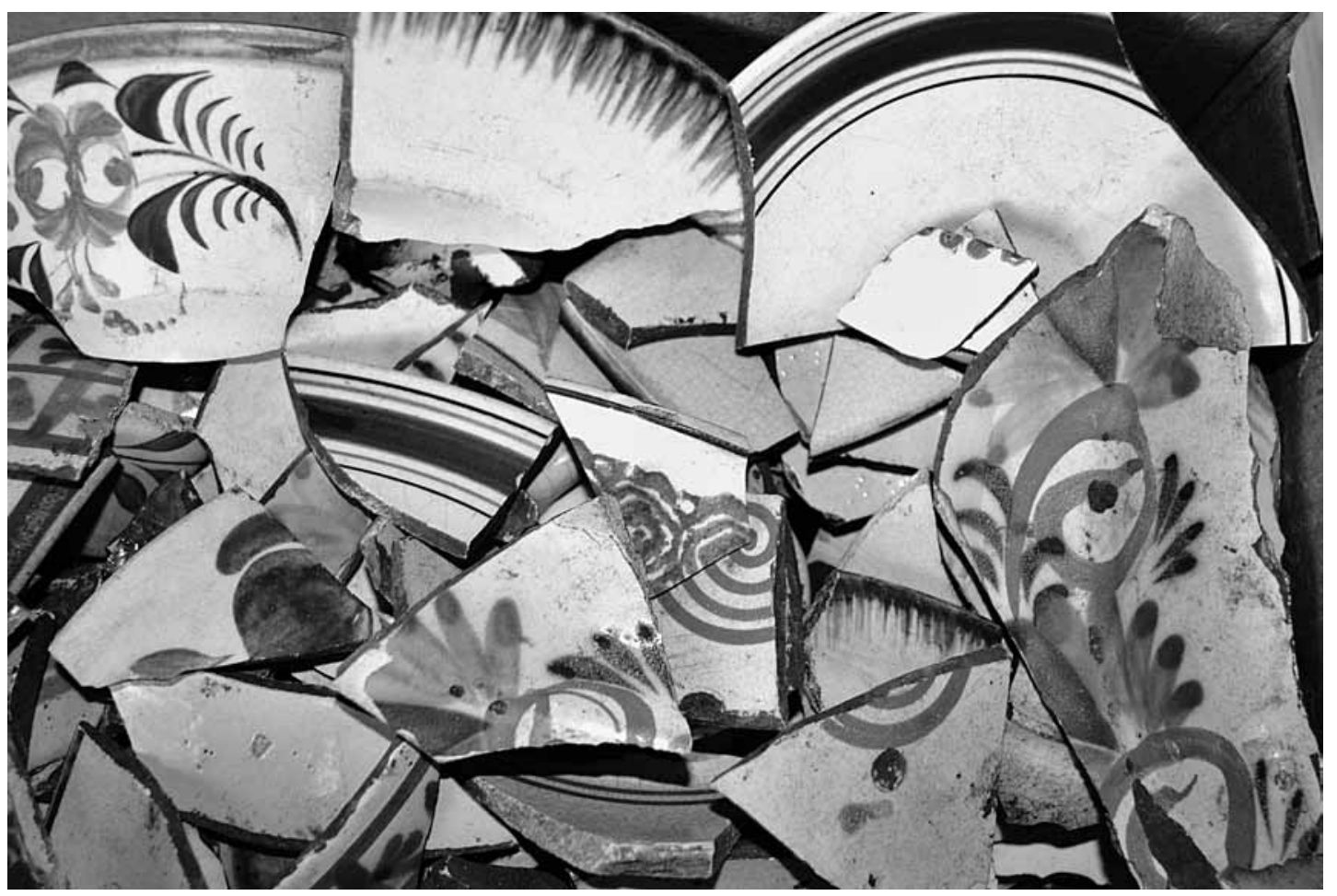

Figure 5. Dona Vera's collection of historical remains. Photograph by Antonio Garcia.

Fragmentos de la colección de restos históricos de Doña Vera. Fotografía de Antonio Garcia. 
attitudes of residents. During the last field season, artifact donations and site visits by local communities increased significantly. Children in the village also collect archaeological objects in their backyards, on the roads, in the school grounds and at the beach. They start their own "small private collections," which at first they had hidden from us. Coins are the preferred object for children, and some have collections representing many centuries of Brazilian history.

We carried out a series of interviews with 11 students from the Joanes School, between 10 and 12 years of age. The first two interview stages occurred in the display room organized at the school and a third was done in the ruin area. The display location where we met the children is what Castañeda (2008:52) calls an "ethnographic installation." According to him, it is a place where distinct visions of the world come together, enabling a dialogue that subverts the hierarchical relations between researchers and local communities and opens a space for common interpretations of material culture and constructions of the past. In fact, observation and conversation with residents at the exhibition revealed aspects of their relationships with archaeological heritage that have previously been silenced.

During the interviews, the children informed us that the Indians who lived in the village threw the coins in a well, which lies a few meters away from the school, "when fleeing from the Portuguese", who wanted to take their lands. The historic well is part of the imaginary narratives of the residents who believe the place is full of treasures. When asked which is the most ancient material that they know of, the students say in chorus, "the coins!". The display windows in the small exhibition show distinct pieces, but the coins are the reference of antiquity for the children. According to the children, "they are very old because when they [Indians] were born the coins already existed and so they were able to buy everything that was there [behind the display window]". In their perspective, the coins belonged to the Portuguese, but their last owners were the Indians, who threw them into the well and other places in the village. Research has shown that children in exceptional situations, such as wars, practice collecting as a means of minimizing their feeling of loss (Belk 2008), as "children perceive, react and add to the world through material culture as objects guide the child's experience" (Deverenski 2000:xv).
Through the perspective of the children of Joanes, the coin collections constitute a direct connection to the village past and, to a certain extent, to the Indian's loss of their land to the Portuguese.

Land ownership has a central role in the lives of Amazonian populations. In fact, some historians affirm that the history of Brazil is fundamentally a history of conflicts over land. It is no surprise that the children who are experiencing this reality so vividly visualize the Indians' most precious asset -their land- being usurped by Europeans, and react to this loss by casting the precious metal of the Portuguese into the bottom of a well that remains inaccessible today. Although they talk much about Indians, the children, like most of the residents of Joanes, affirm that they have no common heritage with the native groups that previously inhabited the island. They perceive local heritage as part of the history of the indigenous people and Europeans. On the other hand, the children's interpretation of the relationships between indigenous people and the Portuguese increases their interest in the coins, giving meaning to the indigenous material culture.

Belk (2008:534) affirms that collecting is a "ritual act of reverence" in which the collector removes the object from a situation of devaluation, "thereby sacralizing them a part of the collection". The collections put together by residents -elders or children- do not constitute acts opposed to preservation and to appropriation, but on the contrary, support the re-design of their past. This is a paradox of preservation policies, which restricts such practices. By restraining these acts, the state has been promoting and patronizing educational projects concerning heritage which ultimately ignore the local communities as active subjects in constructing the patrimony and the past.

\section{The Ruins as Practiced Landscapes}

The ruins rarely appear in children's narratives; nonetheless, during the interviews, they talked about playing at the site and describe ghosts, supernatural tales, or visages (a native category) that appear around it. The ruins serve as a path to the edge of the cliff, to the lighthouse area and to the back of the new church, where the children like to play. Older residents also tell stories about the hide-and-seek games in the same place and speak of the ruins area as a route for hikes. Both the adults and the children refer to the old lighthouse, to the 
historic well, to the beach and to the creek, but they rarely mention the ruins. It is curious that many of the places cited are located in the area around the ruins and it is necessary to cross the ruins in order to reach them.

The ruins are naturalized by the residents and are part of their daily landscape; there is no strangeness between them. The ruins do not seem to have a declared significance, but are always present in their memories. D. Maria José states, "Ever since I can remember, the ruins have always been there". They do not live in these ruins, but the ruins live in them through their imagination. The residents' memories concerning the ruins have to do with the affective domain and to the "past that becomes the present" (Sarlo 2007). The ruins of Joanes are landscapes that have been lived and experienced over generations. To ignore this "poetics of space" (Bachelard 2008) in Joanes is to treat heritage as a "government technology", as Smith calls it (2007:169). Government technology is the use of the sacralization of places and objects as a political tool, at the local communities' expense.

\section{Conclusion}

The relationships between the local communities in Joanes and archaeological heritage are not of simple destruction which results from ignorance. In the studied case, the logic of heritage comes into conflict with the perception that these residents have of "places and objects". The discourse of heritage essentializes the sacralization of the past and its material testimonies; the local residents, for their part, sacralize the past by re-signifying the ancient "places and objects" in their daily lives. The mismatch between these two visions is characteristic of relations that "do not happen between equals" (Barretto 2003:25), but that have nonetheless guided the policies for protecting archaeological heritage in Brazil (Bezerra de Almeida 2003).

These conflicts have their origin in the idea of heritage itself, which in essence is contrary to the processes of self-recognition and attribution of identities. The discourse of heritage defines heritage and elects its "heirs". The development of public archaeology projects carried out through a dialogue between distinct "semantic horizons" (Cardoso de Oliveira 1998:24) can de-center the management of heritage and move towards legitimization of the past of small communities in the Amazon. Our key challenge in the Amazon is to deconstruct these assymetrical relationships. In this sense, discussing whether or not collecting can "harm" the past (Scarre 2006) is just as important as understanding why people "collect the past".

Acknowledgments: To CNPq for financial support, to the local communities of Joanes for their generosity and for authorizing the use of their photographs, interviews and names, to K. Anne Pyburn, IU consultant of the project, to Flávio da Silveira of UFPA for his comments and to the anonymous referees for their critics and suggestions.

\section{References Cited}

Bachelard, G. 2008. A Poética do Espaço. Martins Fontes, São Paulo.

Barretto, M. 2003. O imprescindível aporte das ciências sociais para o planejamento e a compreensão do Turismo. Horizontes Antropológicos 20:7-11.

Belk, R. 2008. Collectors and collecting. In Handbook of Material Culture, edited by C. Tilley, S. Keane, S. Kuchler, M. Rowlands, and P. Spyer, pp. 534-545. Sage, Thousand Oaks.

Bezerra, M. 2009. Por cima é balangandã, por baixo molambo só: os moradores, as paisagens e as ruínas en um projeto de Arqueologia no Centro Histórico de Salvador/Bahia. In Paisagem e Cultura: Dinâmicas do Patrimônio e da Memória na Atualidade, edited by F.L.A. Silveira and C.D. Cancela, pp. 63-70. Universidade Federal do Pará, Belém.

- - - 2010. Nossa herança comum: considerações sobre a Educação Patrimonial na Arqueologia Amazônica. In Arqueologia
Amazônica Vol. 1, edited by E. Pereira and V. Guapindaia. pp. 1021-1035. Museu Paraense Emilio Goeldi, Instituto do Patrimônio Histórico e Artístico Nacional, Secretaria de Estado de Cultura do Pará, Belém.

Bezerra de Almeida, M. 2003. O público e o patrimônio arqueológico: Reflexões para a arqueologia pública no Brasil. Habitus 1:275-295.

Brochado, J.P. 1980. Social Ecology of the Marajoara Culture. Master's thesis. Department of Anthropology, University of Illinois,Urbana-Champaign.

Brodie, N. 2006. Introduction. In Archaeology, Cultural Heritage and the Antiquities Trade, edited by N. Brodie, M. Kersel, C. Luke and K.W. Tubb, pp. 1-24. University of Florida Press, Gainesville.

Cabral, M.P., and J.D.M. Saldanha 2008. Paisagens megalíticas na costa norte do Amapá. Revista de Arqueologia 1:9-26. 
Cardoso de Oliveira, R. 1998. O Trabalho do Antropólogo. Paralelo 15. UNESP, São Paulo.

Castañeda, Q.E 2008. The "Ethnographic Turn" in archaeology. Research positioning and reflexivity in ethnographic archaeologies. In Ethnographic Archaeologies: Reflections on Stakeholders and Archaeological Practices, edited by Q.E. Castañeda and C.N. Matthews, pp. 25-61. Altamira, New York.

Colwell-Chanthaphonh, C., and T.J. Ferguson (eds.) 2008. Collaboration in Archaeological Practice: Engaging Descendants Communities. Altamira, New York.

Deverenski, J.S. 2000. Preface. In Children and Material Culture, edited by J.S. Deverenski, pp. xv-xvii, Routledge, New York.

Deetz, J. 1996. In Small Things Forgotten: An Archaeology of Early American Life. Anchor Books/Doubleday, New York.

Elias, N., and J.L. Scotson 2000. Os Estabelecidos e os Outsiders: Sociologia das Relações de Poder a Partir de uma Pequena Comunidade. Jorge Zahar, Rio de Janeiro.

Fausto, B. 2003. História do Brasil. EDUSP, São Paulo.

Gnecco, C., and P. Ayala (eds.) 2011. Indigenous People and Archaeology in Latin America. Left Coast Press, Walnut Creek, California.

Gnecco, C., and C. Hernandez 2008. History and its discontents: Stone statues, native histories, and archaeologists. Current Anthropology 49:439-466.

Green, L.F., D.R. Green, and E.G. Neves 2003. Indigenous knowledge and archaeological science. Journal of Social Archaeology 3:365-397.

Guapindaia, V. 2008. Prehistoric funeral practices in the Brazilian Amazon: The Maracá urns. In The Handbook of South American Archaeology, edited by H. Silverman and W.H. Isbell, pp. 10051026. Springer, New York.

Heckenberger, M.J. 2005. The Ecology of Power: Culture, Place, and Personhood in the Southern Amazon, AD 10002000. Routledge, New York

IPHAN 2006. Coletânea de Leis Sobre Preservação do Patrimônio. IPHAN, Rio de Janeiro.

Lima, H. 2007. Projeto baixo Amazonas. Presented in $I$ Seminário Internacional de Gestão do Patrimônio Arqueológico Amazônico, Manaus.

Londoño, W. 2003. Discurso jurídico versus discurso cultural. El conflicto social sobre los significados de la cultura material prehispánica. Boletín del Museo del Oro 51:1-26.

Lopes, P.R. do C. 1999. A Colonização Portuguesa da Ilha de Marajó: Espaço e Contexto Arqueológico-histórico na Missão Religiosa de Joanes. Departamento de História, Pontifícia Universidade Católica do Rio Grande do Sul, Porto Alegre.

Marques, F.LT., and M. Bezerra 2008. Projeto de pesquisa arqueológica e educação patrimonial na Vila de Joanes, Marajó Island. Manuscript in possession of the authors.

- - - 2009. Projeto de pesquisa arqueológica e educação patrimonial na Vila de Joanes, Marajó Island. Manuscript in possession of the authors.
Meggers, B.J., and C. Evans 1954. Uma Interpretação das Culturas da Ilha do Marajó. Instituto de Antropologia e Etnologia do Pará 7. Instituto de Antropologia e Etnologia do Pará, Belém.

Mello e Souza, L. 1997. Formas provisórias de existência: a vida cotidiana nos caminhos, nas fronteiras e nas fortificações. In História da Vida Privada no Brasil: Cotidiano e vida privada na América Portuguesa, edited by L. Mello e Souza, pp. 41-81. Companhia das Letras, São Paulo.

Miller, D. (ed.) 2005. Materiality. Duke University Press, Durham.

Petersen, J.B., E. Neves, and M.J. Heckenberger 2001. Gift from the past: terra preta and prehistoric Amerindian occupation in Amazonia. In Unknown Amazon: Culture in Nature in Ancient Brazil, edited by C. McEwan, C. Barreto, and E. Neves, pp. 86105. British Museum Press, London.

Pereira, E. 2003. Arte Rupestre na Amazônia - Pará. UNESP, São Paulo.

Roosevelt, A.C. 1991. Moundbuilders of Amazon: Geophysical Archaeology on Marajó Island, Brazil. Studies in Archaeology. Academic Press, New York.

Sarlo, B. 2007. Tempo Passado: Cultura da Memória e Guinada Subjetiva. Companhia das Letras, São Paulo.

Scarre, G. 2006. Can archaeology harm the dead? In The Ethics of Archaeology: Philosophical Perspectives on Archaeological Practice, edited by C. Scarre and G. Scarre, pp. 181-198. Cambridge University Press, Cambridge.

Schaan, D. 2001. Into the labyrinths of Marajoara pottery: status and cultural identity in prehistoric Amazônia. In Unknown Amazonia: Culture in Nature in Ancient Brazil, edited by C. McEwan, C. Barreto and E. Neves, pp. 108-133. British Museum Press, London.

- - - 2007. Múltiplas vozes, memórias e histórias: por uma gestão compartilhada do patrimônio arqueológico na Amazônia. Revista do IPHAN 33:109-136.

- - - 2009a. Sobre índios e portugueses: arqueologia e história da Ilha do Marajó. In Marajó: Arqueologia, Iconografia, História e Patrimônio - Textos Selecionados, edited by D.P. Schaan. pp. 29-42. Habilis, Erechim.

- - - 2009b. Cultura Marajoara. Senac Nacional, Rio de Janeiro.

Schaan, D., and F.L.T. Marques 2006. Projeto: Preservação, conservação, pesquisa e educação patrimonial no sítio histórico de Joanes. Manuscript in possession of the authors.

Schaan, D., A. Ranzi and M. Parssinen 2008. Arqueologia da Amazônia Ocidental: Os Geoglifos do Acre. Editora da Universidade Federal do Pará, Belém.

Silveira, M.I., and D.P. Schaan 2005. Onde a Amazônia encontra o mar: estudando os sambaquis do Pará. Revista de Arqueologia 18:67-79.

Smith, L. 2007. Empty gestures? Heritage and the politics of recognition. In Cultural Heritage and Human Rights, edited by H. Silverman and D.F. Ruggles, pp. 159-171. Springer, New York. 


\section{Dataciones radiocarbónicas NO deberían demorar una eternidad}

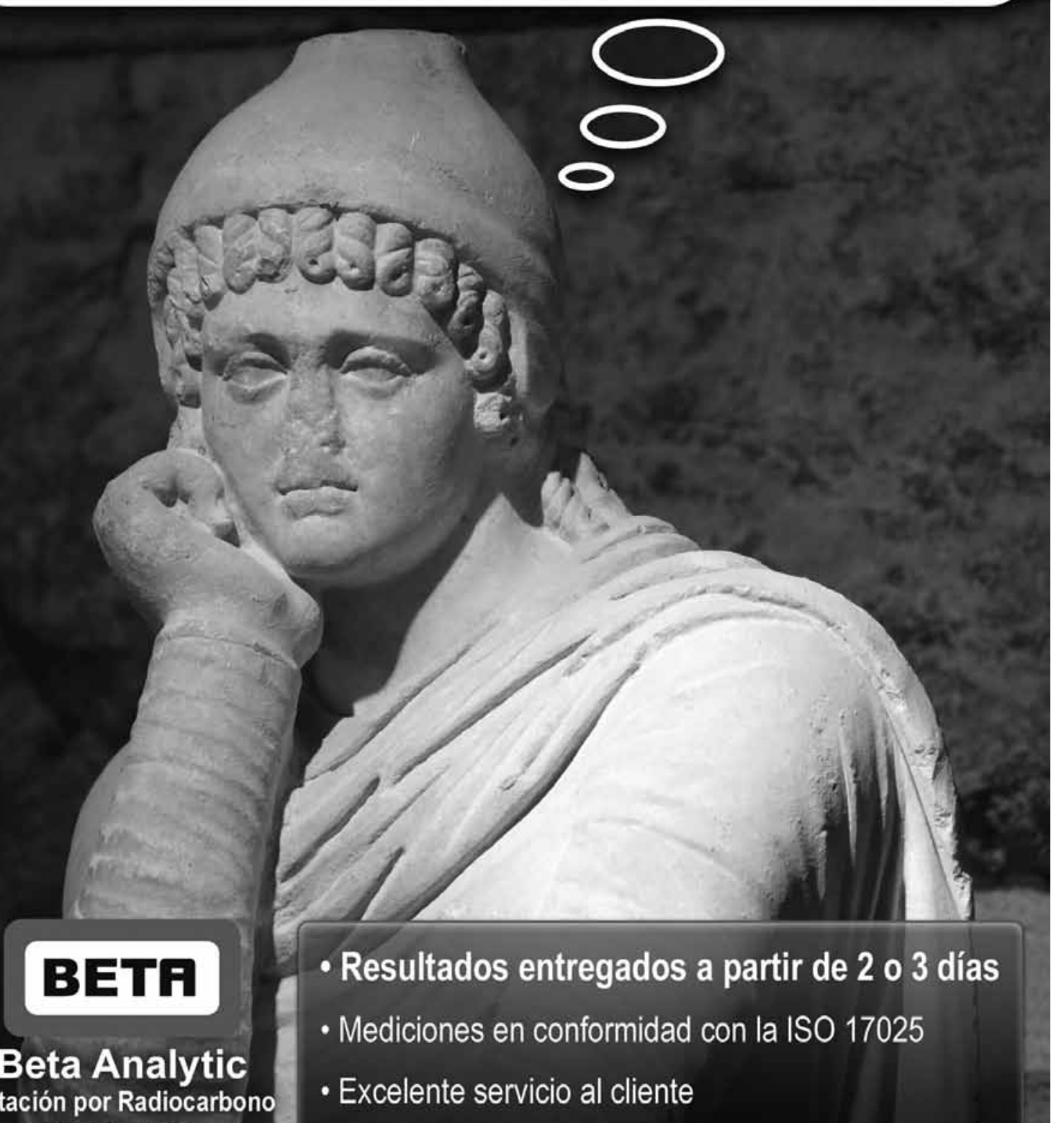

Datación por Radiocarbono

Desde 1979

Australia Brasil China India Japón UK EE.UU Visite www.radiocarbon.com para obtener detalles 
ANDROS IMPRESORES

www.androsimpresores.cl 